\title{
Characterization of enclosure management regimes and factors influencing their choice among agropastoralists in North-Western Kenya
}

\author{
John Ndung'u Wairore ${ }^{1,3^{*}}$, Stephen Mwangi Mureithi ${ }^{1,3}$, Oliver Vivian Wasonga ${ }^{1}$ and Gert Nyberg ${ }^{2,3}$
}

\begin{abstract}
The enclosure system is an increasingly popular approach for land rehabilitation among communities inhabiting the arid and semi-arid lands in Africa. However, the mixed results associated with its adoption by households call for an in-depth understanding of the management regimes. This study was conducted in Chepareria ward in West Pokot County to characterize enclosure management regimes and determine factors which influence their choice among agropastoralists in Chepareria.

Enclosures in Chepareria were mainly used for livestock-based agropastoralism (78.3\%) while crop-based agropastoralism accounts for $21.7 \%$. The dominance of livestock-based enclosure management regimes in Chepareria indicates that livestock production is still the mainstay of agropastoralists in Chepareria while diversification of land use is common where rain-fed agriculture allows as evidenced by the adoption of crop-based enclosure regimes in the wetter regions of Chepareria. The choice of management regimes was mainly influenced by agroecological zonation and land tenure $(P \leq 0.01)$, and number of livestock owned and household income $(P \leq 0.05)$.

Enclosures were mainly established to alleviate pasture scarcity and create stable environments for the local Pokot pastoral community by restoring degraded rangelands. However, the continuous adoption and adaptation of enclosures has enabled agricultural diversification by increasing flexibility on land, fodder and livestock management including the adoption of alternative income-generating activities among enclosure owners in Chepareria. Enclosure owners may continue to diversify or intensify enclosure management regimes as influenced by agroecological zonation, land tenure, number of livestock owned and household income.
\end{abstract}

Keywords: Agropastoralists; Enclosure; Rangelands; Rehabilitation; Triple L; West Pokot

\section{Background}

The use of enclosures is an increasingly popular approach for rehabilitating degraded lands in Africa. Land degradation remains, however, a key environmental concern globally, especially in the drylands which cover about $41 \%$ of the land area globally (MA 2005), $43 \%$ in Africa (AUIBAR 2012) and $22 \%$ in Kenya (Kirui and Mirzabaev 2014). Drylands are home to more than two billion people in the world (Reynolds et al. 2007), $90 \%$ of whom live in developing countries (UNEP 2007). In Kenya, a country where up to a third of the its population directly depends

\footnotetext{
* Correspondence: jwairore@gmail.com

'Department of Land Resource Management and Agricultural Technology (LARMAT), University of Nairobi, P.O. Box 29053-00625, Nairobi, Kenya

${ }^{3}$ Triple L Research Initiative, Uppsala, Sweden

Full list of author information is available at the end of the article
}

on land that is already degraded or in the process (Bai and Dent 2006), the need to address land degradation in rangelands cannot be underestimated. Previous attempts to rehabilitate/restore degraded rangelands globally (MA 2005; AU-IBAR 2012) and in Kenya (Mureithi et al. 2010) have failed. However, enclosures have emerged as a successful management tool for the rehabilitation of degraded rangelands as evidenced by studies in East Africa (Behnke 1986; Gaani et al. 2002; Nedessa et al. 2005; Mekuria et al. 2007; Keene 2008; Mwilawa et al. 2008; Beyene 2010) and in Kenya (Kitalyi et al. 2002; Wasonga 2009; Verdoodt et al. 2009, 2010, 2013; Mureithi et al. 2010; Opiyo et al. 2011; Kigomo and Muturi 2013).

In a bid to address land degradation as an emerging ecological and socio-economic challenge in Chepareria, the Vi Agroforestry (Vi-AF) organization conducted intensive 
extension on agroforestry and enclosure establishment in Chepareria (Makokha et al. 1999). The continuous adoption and adaptation of private enclosures since they were first introduced in 1987 was influenced by several factors, among them increasing land degradation and drought which resulted in general scarcity of good grazing (Makokha et al. 1999). Private enclosures were established to address land degradation in Chepareria by providing flexibility in land, fodder and livestock management including the adoption of alternative income-generating activities (Wairore 2015).

Despite the general success of enclosure in rangeland rehabilitation, the variability of rehabilitation success in Chepareria (Makokha et al. 1999) and in Baringo rangelands (Verdoodt et al. 2010) has pointed out that individual management decisions play a critical role in promoting successful rangeland rehabilitation. There are observed difficulties in managing enclosed areas in Chepareria (Makokha et al. 1999), restoring vegetation in some private enclosures with lower biomass in Baringo (Verdoodt et al. 2010) and interpreting already collected data on soil organic carbon (SOC) in Chepareria (Svanlund 2014). These difficulties have raised pertinent questions on the possibilities of presently rehabilitated rangelands in Chepareria reverting to their previously degraded state due to inappropriate private enclosure management systems.

A few studies have documented the management of private enclosures (Mureithi et al. 2010; Verdoodt et al. 2010). While these studies outlined the utilization of communal and private enclosures in the Lake Baringo Basin, there are increasing calls for further investigation on the applied past and present management systems of private enclosures in Chepareria (Svanlund 2014). Studies have been conducted on driving forces in the expansion of enclosures (Beyene 2010). However, limited information exists on factors influencing the choice of enclosure management regimes/systems. In discerning enclosure management regimes and factors influencing their choice, we reiterate the concerns of Keene (2008) in questioning what could right holders do with their enclosures.

This paper therefore seeks to characterize enclosure management regimes and identify factors which influence their choice among agropastoralists in Chepareria. This information will enable interpretation of already collected enclosure data and may also be used as a guide to identify areas of action in enclosure decision-making, management and the development of appropriate and productive enclosure management strategies to ensure that enclosed areas in Chepareria do not revert to their previously degraded state.

\section{Study area}

The study site is located in Chepareria ward within latitude $1^{\circ} 15^{\prime}$ and $1^{\circ} 55^{\prime} \mathrm{N}$ and longitude $35^{\circ} 7^{\prime}$ and $35^{\circ} 27^{\prime} \mathrm{E}$ in
North-Western Kenya (Fig. 1). The area has gently undulating plains surrounded by mountain ranges with peaks of up to $3,000 \mathrm{~m}$. Rainfall in Chepareria averages $600 \mathrm{~mm}$ per year. According to the National Drought Management Authority (NDMA), Chepareria has a bimodal rainfall pattern, with a long rainy period between March and May and short rainy period from August to November (NDMA 2014). The average annual temperature in West Pokot County ranges from $15{ }^{\circ} \mathrm{C}$ to $30{ }^{\circ} \mathrm{C}$ in the highlands and $24{ }^{\circ} \mathrm{C}$ to $38{ }^{\circ} \mathrm{C}$ in the lowlands (County Government of West Pokot 2013).

The soil types vary from shallow and friable in the lowlands to deep, well-drained, reddish brown sandy loams in the upper regions of Chepareria while soil fertility varies from low to moderate (Sposito 2013). The vegetation is mainly steppe-like, dominated by grasslands and interspersed native and exotic tree species. Some of the dominant native tree species include Terminalia brownie, Balanites aegyptiaca and Kigelia africana, among others, while the introduced tree species include Croton spp., Azadirachta indica, Grevillea robusta and Ficus spp. (Svanlund 2014).

According to the Kenya National Bureau of Statistics (KNBS), the population of Chepareria ward is approximately 41,563 persons (KNBS 2009). The Pokot community is the dominant tribe in the study area. Though originally a pastoral community, they have diversified into other forms of production to meet livelihood needs. There is a great variation in rainfall received (total amount and distribution) within Chepareria influencing livelihood zones as indicated in Fig. 2. Ywalateke location which is on the higher areas of Chepareria is mainly a mixed farming area, while the lower areas of Chepkopegh and Morpus locations are agropastoral livelihood zones (Fig. 2).

\section{Enclosures in Chepareria}

Many dryland areas in sub-Saharan Africa (SSA) have a history of overgrazing and land degradation resulting in low productivity, frequent droughts, conflicts over resources and marginalization (economic and political) of pastoral communities (Opiyo et al. 2011). The use of enclosures as a management tool for the rehabilitation of degraded rangelands in Chepareria and the Lake Baringo Basin has proven that it is a successful restoration approach/technique in drylands (Makokha et al. 1999; Mureithi et al. 2010). In Chepareria, enclosures were mainly established for land rehabilitation, fodder production, land and livestock management (Kitalyi et al. 2002). Since 1987 when enclosures were first introduced by $\mathrm{Vi}$-AF to address land degradation and increase fodder production in Chepareria, the use of enclosures as a management tool has been high. By offering flexibility in fodder, land and livestock management, Chepareria residents have not only been able to reduce land degradation 


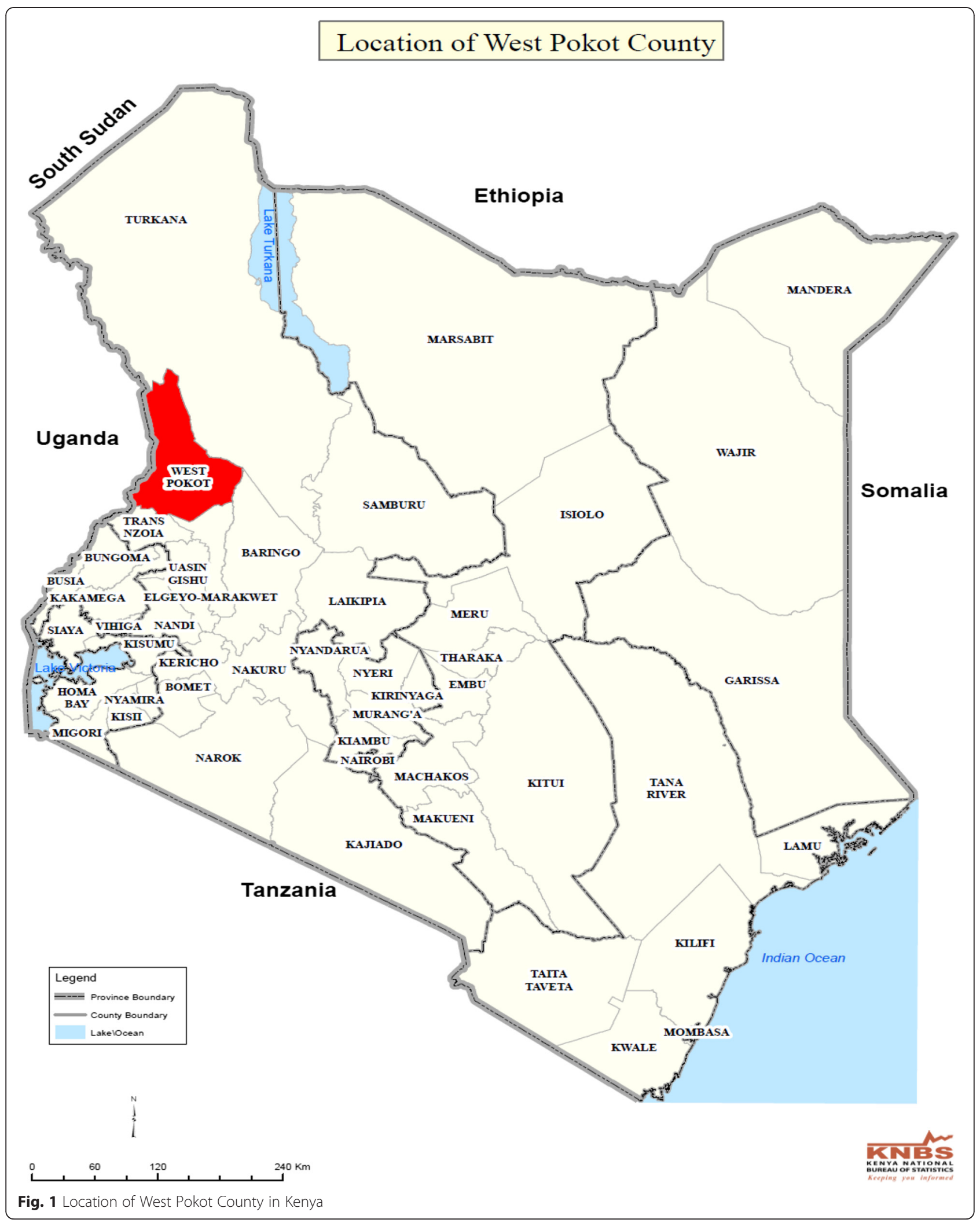




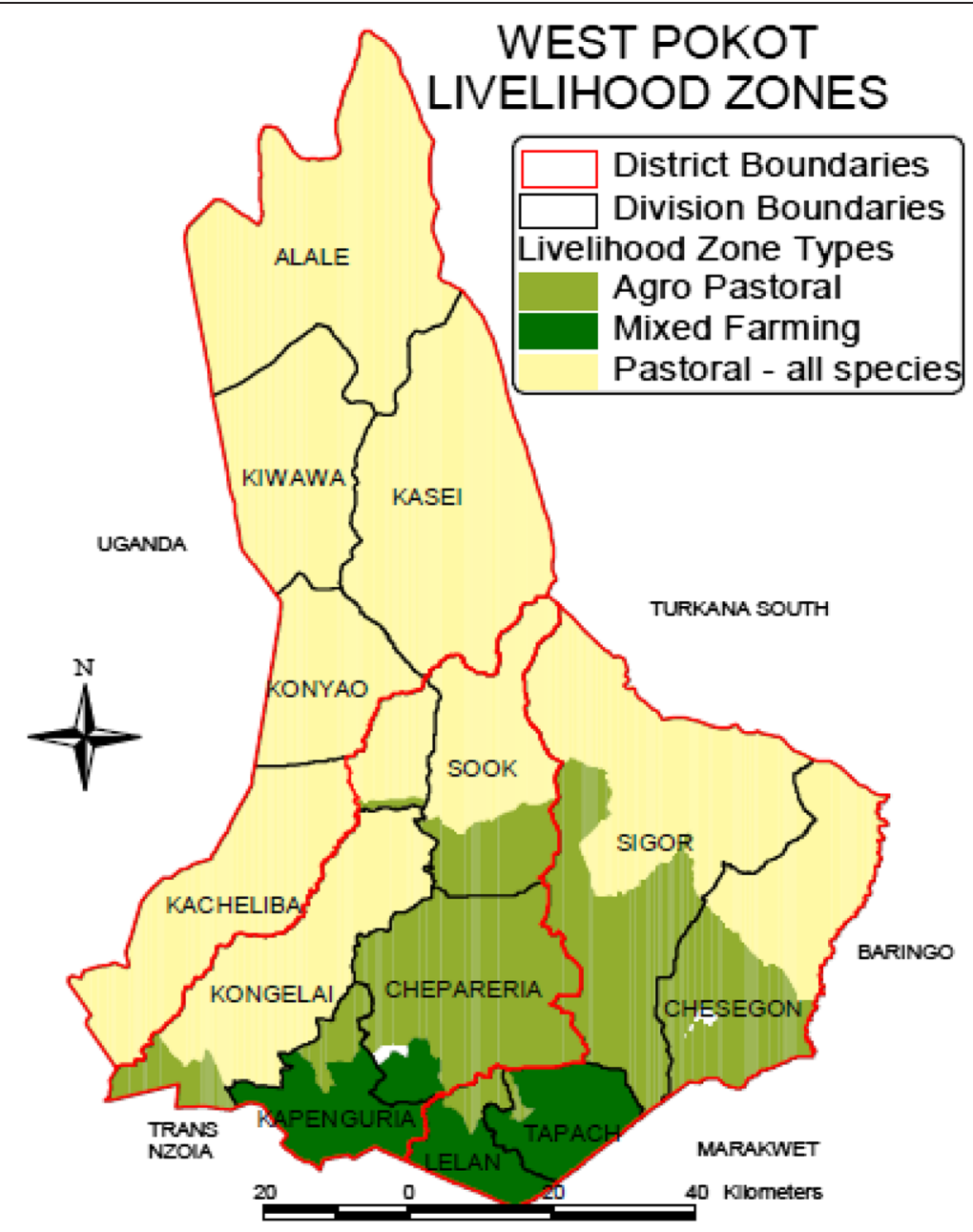

Fig. 2 West Pokot County livelihood zones. Source: Drought Early Warning Bulletin - West Pokot County (NDMA 2014)

but have also witnessed a transformation in livelihoods, land use and agricultural production systems (Wairore 2015). Due to the continuous adoption and adaptation of enclosures witnessed in the ward, enclosures are now the dominant form of land management, one which is fostering agricultural system diversification in Chepareria.

\section{Methods}

\section{Data collection}

Purposive sampling was used to select Chepareria ward for this study. This is an area where NGO Vi Agroforestry conducted intensive extension on agroforestry and enclosure establishment in West Pokot County. The study was conducted in the three locations of Chepareria where Vi Agroforestry was active, namely Ywalateke, Chepkopegh and Morpus.

Using a checklist of more than 400 enclosure owners in each location, systematic random sampling was used to select 40 enclosure owners in each of the three locations in Chepareria ward to attain a sample of 120 households.
A semi-structured questionnaire was used to collect data on household demographic characteristics, age of enclosure since establishment, the number and size of enclosure, enclosure income, enclosure management practices/regimes, enclosure ownership and distance from enclosure to tarmac and Chepareria market. Focus group discussions (FGDs) and key informant interviews (KIIs) were used to complement the information gathered through the semi-structured questionnaire. Five KIIs and eight FGDs were conducted to clarify and give more insights on aspects of enclosure management, ownership/tenure, size and reasons for enclosure establishment. Literature review was used to contextualize the study while observation was critical in identifying the stated management systems.

\section{Data analysis}

The collected data were analysed using the Statistical Package for the Social Sciences (SPSS). Descriptive statistics were used to determine the applied enclosure management systems/regimes. The results were presented in forms of 
percentages, means/averages and standard deviations (SD). Further, bivariate correlations were done to determine factors influencing the choice of enclosure management regimes among agropastoralists in Chepareria. Pearson's coefficient two-tailed test of significance was used to detect significant correlations between enclosure management systems and the various hypothesized factors.

\section{Description of factors hypothesized to influence the choice of enclosure management regimes}

Agroecological zonation (AEZ). The humid and wet regions will support rain-fed agriculture hence cropbased enclosure regimes while the drier areas are more likely to support livestock-based management regimes. Agroecological zonation is hypothesized to have a negative effect on enclosure regimes.

Land tenure. Individuals with title deeds are more likely to adopt crop-based regimes while those still operating under the group ranch scheme have a livestock-based management system. Formalization of land tenure is hypothesized to encourage diversification in management regimes.

Age of household head (years). The age of the household head $(\mathrm{HH})$ influences their access to education. It is therefore likely that the age of the household head will negatively influence management regimes in that the younger enclosure owners, in this case youths (18 to 35 years), will adopt improved and productive management regimes in a bid to diversify income derived from enclosure use.

Education level of household head. Education is an important entry point for the empowerment of pastoral communities. In enclosure management, the education level of pastoral households may be significant in identifying appropriate enclosure management systems for sustainable land management. Education plays a significant role in influencing household income, technology adoption and the socio-economic status of the family as a whole (Ejigu et al. 2009) and is hypothesized to positively influence enclosure regimes.

Livestock owned. The number of livestock in a household is likely to positively influence applied enclosure management regimes or systems. This hypothesis is likely to hold if there is a positive significant correlation between the number of livestock owned and total household income. Households with large herds will practise livestock-based agropastoralism while those with smaller herds are likely to adopt enclosure regimes with complementary or subsistence land use practices.

Enclosure acreage (ha). Households with large enclosure sizes are likely to practise livestock-based agropastoralism due to adequacy of pasture, particularly during the dry season. They are also likely to diversify income by engaging in other income-generating land use options such as contractual grazing. On the other hand, those with smaller enclosures are likely to practise crop-based agropastoralism where rains permit. In areas with poor rainfall, they are likely to practise livestock-dominated regimes with complementary crop and fodder production to supplement livestock pasture particularly during critical grazing periods.

Distance to market $(\mathrm{km})$. Households with proximity to markets are more likely to adopt market-oriented production practices compared to households located far from such markets. It is hypothesized that distance to market will negatively influence enclosure regimes with those closer to the market practising market-oriented livestock or crop-dominated production practices.

Household income (US\$). It is hypothesized that rich households are more likely inclined to practise diverse land use practices than the poor since agropastoralists in the former do not find sufficient feeds for their large herds in times of grazing scarcity. Since this research was conducted in 2014, household income was determined based on the preceding year - 2013.

\section{Results}

\section{Household and enclosure characteristics of the sampled population}

Most (73.3 \%) of the households interviewed were headed by males. The majority ( $42.5 \%)$ of the respondents were aged between 36 and 50 years. The respondents under 36 years made $37.5 \%$, while those over 50 years made $20 \%$ of the sample. The majority of the respondents $(56.3 \%)$ had attained basic primary education, while $8.4 \%$ had attained secondary education. Only $5.9 \%$ had attained post-secondary education. However, education is still a challenge as $29.4 \%$ of the respondents had not gone through formal education. The household had an average family size of $7 \pm 3( \pm \mathrm{SD})$.

The enclosure survey showed that $51.7 \%$ of respondents formally own the enclosed areas through title deeds or allotment letters. On the other hand, $48.3 \%$ of the respondents informally own land which is still held under the group ranch scheme. Most enclosures were established 16 years ago and have an average acreage of 5.01 ha. Other characteristics of sampled enclosures in Chepareria are indicated in Table 1.

\section{Enclosure management regimes}

Across the study area, livestock-based regimes were found to account for $78.3 \%$ while crop-based regimes accounted for $21.7 \%$ of the sampled enclosures. Within the livestock-based regimes, grazing and cultivation; grazing, cultivation and contractual grazing; and grazing, cultivation and fodder production were found to account for $60 \%, 13.3 \%$ and $5 \%$, respectively. On the other hand, crop-based agropastoralism was comprised of the 
Table 1 Characteristics of selected enclosures in Chepareria

\begin{tabular}{llll}
\hline Enclosure characteristics & Minimum & Maximum & Mean (SD) \\
\hline Age (years) & 0 & 47 & $16.17(10.98)$ \\
Distance to tarmac $(\mathrm{km})$ & 0 & 13.5 & $3.92(3.58)$ \\
Distance to market $(\mathrm{km})$ & 1 & 22 & $9.19(4.09)$ \\
Acreage (ha) & 0.4 & 24.38 & $5.01(4.38)$ \\
Number of livestock owned & 1 & 42 & $7.85(7)$ \\
Household income $^{\mathrm{a}}$ (US\$) & 92.59 & $6,273.15$ & $1,046.10(995.68)$ \\
\hline
\end{tabular}

${ }^{\mathrm{a}}$ Exchange rate as of 31 December 2013 was 1 US $\$=86.40$ Kenyan shilling

crop-dominated cultivation and grazing (21.7 \%) enclosure regime. Although the introduction of enclosures has led to reduced migration with livestock and more sedentary lifestyles, the results show that livestock production is still the mainstay of most agropastoral households in Chepareria as evidenced by the dominance of the livestock-based enclosure regimes in Table 2.

On location basis, Chepkopegh (85.0 \%) and Morpus $(86.7 \%)$ are dominated by livestock-based management regimes while crop-based enclosure regimes only accounted for $15 \%$ and $13.3 \%$, respectively. The grazing, farming and contractual grazing regime is higher in Chepkopegh compared to Morpus at $15.1 \%$ and $10 \%$, respectively, while grazing and farming is higher in Morpus (76.7 \%) than in Cheptiangwa (66.7\%). As opposed to the previous two locations, Ywalateke is a mixed farming area with livestockand crop-based management systems accounting for $56.7 \%$ and $43.3 \%$, respectively. The farming and grazing regime accounts for the highest enclosure management system at $43.4 \%$ compared to grazing and farming at $30 \%$. Farming, grazing and fodder production and grazing, cultivation and contractual grazing are practised equally in Ywalateke at $13.3 \%$ (Table 2).

\section{Factors influencing the choice of enclosure management regimes}

Of the eight factors hypothesized to influence the choice of enclosure management regimes among agropastoralists in Chepareria, only four factors (number of livestock owned, household income, agroecological zonation and land tenure) were significant as indicated in Table 3. A significant positive correlation exists between enclosure management systems and household income $(P \leq 0.05)$ and number of livestock owned $(P \leq 0.05)$. On the other hand, a significant negative correlation between enclosure regimes and agroecological zonation $(P \leq 0.01)$ and land tenure $(P \leq 0.01)$ was detected.

\section{Discussion}

\section{Enclosure management regimes/systems}

Enclosure management regimes showcase the various possible combinations of production practices carried out by individual enclosure owners on rehabilitated land. The presence of different enclosure regimes in the formerly degraded lands provides enclosure owners in Chepareria with the opportunity to enhance flexibility in fodder production, land and livestock management. This enables them to ensure that restored areas do not revert to their previously degraded state, optimize on land use and diversify livelihoods to cushion households from various climatic and market shocks.

Enclosure management regimes integrate various land use options or enterprises as enclosure owners attempt to optimize and diversify on land use. Livestock-based management regimes are livestock-dominated systems whose main objective is to support livestock production. They also integrate other complementary or subsistence land use practices to either support livestock production or for sustenance. On the other hand, crop-based regimes are cultivation-dominated management systems whose main goal is to produce food crops for own consumption or for sale. Similarly, they also integrate other complementary or subsistence land use practices.

\section{Livestock-based enclosure management systems}

Variations observed across the locations in the adoption of the grazing and cultivation enclosure management system can be attributed to climatic differences across the study area. Morpus and Chepkopegh locations are in the drier, low altitude regions of Chepareria (Agroecological Zone

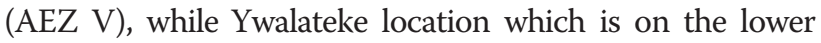
slopes of Kamatira hills is in AEZ IV. Climate variability

Table 2 Enclosure management regimes and practices in Chepareria

\begin{tabular}{|c|c|c|c|c|c|c|}
\hline \multirow[t]{3}{*}{ Location/site } & \multicolumn{6}{|c|}{ Frequency of enclosure management regime (\%) } \\
\hline & \multicolumn{4}{|c|}{ Livestock-based agropastoralism } & \multicolumn{2}{|c|}{ Crop-based agropastoralism } \\
\hline & Grazing and cultivation & $\begin{array}{l}\text { Grazing, cultivation and } \\
\text { contractual grazing }\end{array}$ & $\begin{array}{l}\text { Grazing, cultivation and } \\
\text { fodder production }\end{array}$ & Total & $\begin{array}{l}\text { Cultivation and } \\
\text { grazing }\end{array}$ & Total \\
\hline Ywalateke & 30 & 13.3 & 13.3 & 56.6 & 43.4 & 43.4 \\
\hline Chepkopegh & 66.7 & 15 & 3.3 & 85 & 15 & 15 \\
\hline Morpus & 76.7 & 10 & 0 & 86.7 & 13.3 & 13.3 \\
\hline Average Chepareria ward & 60 & 13.3 & 5 & 78.3 & 21.7 & 21.7 \\
\hline
\end{tabular}


Table 3 Factors influencing the choice of enclosure management regimes in Chepareria

\begin{tabular}{|c|c|c|c|c|c|c|c|}
\hline Variables & $\begin{array}{l}\text { Grazing and } \\
\text { cultivation }(N=72)\end{array}$ & $\begin{array}{l}\text { Grazing, cultivation and } \\
\text { contractual grazing }(N=16)\end{array}$ & $\begin{array}{l}\text { Grazing, Cultivation and } \\
\text { fodder/grass seed } \\
\text { production }(N=6)\end{array}$ & $\begin{array}{l}\text { Cultivation and } \\
\text { grazing }(N=26)\end{array}$ & Mean & $\begin{array}{l}\text { Pearson } \\
\text { correlation }\end{array}$ & $\begin{array}{l}\text { Significance } \\
\text { (two-tailed) }\end{array}$ \\
\hline $\begin{array}{l}\text { Number of livestock } \\
\text { owned }\end{array}$ & 7.43 & 9.43 & 15.00 & 6.48 & 7.85 & 0.209 & $0.024^{*}$ \\
\hline $\begin{array}{l}\text { Enclosure acreage } \\
\text { (ha) }\end{array}$ & 4.99 & 7.59 & 7.08 & 3.02 & 5.01 & 0.147 & 0.109 \\
\hline $\begin{array}{l}\text { Distance to market } \\
(\mathrm{km})\end{array}$ & 9.56 & 10.22 & 6.50 & 8.19 & 9.19 & -0.11 & 0.22 \\
\hline $\begin{array}{l}\text { Household income } \\
\text { (US\$) }\end{array}$ & 899.55 & $1,145.33$ & $1,808.64$ & $1,214.90$ & $1,046.10$ & 0.214 & $0.019^{*}$ \\
\hline Agroecological zone & & & & & & -0.348 & $0.000^{* *}$ \\
\hline Land tenure & & & & & & -0.234 & $0.010^{* *}$ \\
\hline $\begin{array}{l}\text { Age of household } \\
\text { head }\end{array}$ & & & & & & 0.064 & 0.486 \\
\hline $\begin{array}{l}\text { Education level of } \\
\text { the household head }\end{array}$ & & & & & & 0.068 & 0.461 \\
\hline
\end{tabular}

Exchange rate as of 31 December 2013 was 1 US $\$=86.40$ Kenyan shillings. ${ }^{*}$ Correlation is significant at the 0.05 level (two-tailed). ${ }^{*}$ Correlation is significant at the 0.01 level (two-tailed)

and rainfall unpredictability impede crop cultivation within the study area, except in Ywalateke which is humid and receives more rainfall. The grazing and cultivation management regime is practised by more enclosure owners in the drier locations of Chepareria, namely Chepkopegh (66.7 \%) and Morpus (76.7\%), as indicated in Table 2. The dominance of this enclosure regime in the drier areas of Chepareria is supported by previous studies which have observed that well-managed livestock production is more adapted and economically and environmentally efficient in drylands (Neely et al. 2009). It also requires limited capital investment (Kandagor 2005). In Ywalateke, the stable climate and higher rainfall in the mixed farming livelihood zone (Fig. 2) enables individuals to engage in intensive livestock- and crop-based regimes; hence, it is only practised by $30 \%$ of Ywalateke residents.

The grazing, cultivation and contractual grazing management regime indicates that pastoralists are looking for possibilities to diversify income, as observed by Fratkin (2001). Contractual grazing represents a grazing arrangement between households with relatively few animals and those who are better off during the dry season, hence creating access options to pasture for such households and income for the poor households (Beyene 2006, 2011). This enclosure regime reaffirms observations in previous studies which indicated that contractual grazing presents a new form of income generation among enclosure owners, one which would be impossible if the entire range was held communally (Keene 2008; Beyene 2010). Chepkopegh location has the highest percentage of enclosure owners who lease grazing at $15 \%$ owing to the high potential of livestock production in the area. This is due to pasture availability owing to a favourable climate for pasture production and the large enclosure sizes, coupled with the recent developments such as the investments in a meat processing plant by the Kenya Meat Commission (KMC). Intensification of crop-based enclosure regimes such as maize production in Ywalateke has reduced the amount of land available for livestock-based regimes. Consequently, there is increasing demand for additional pasture which translates into high prices for contractual grazing. This tends to tempt some individuals into demarcating some parts of their enclosure for leasing out, hence practised by $13.3 \%$ of the residents in the location. Morpus location located in the lowlands of Chepareria is in AEZ V. Since the region is dry with erratic rainfall, most individuals choose to maintain pasture for dry-season grazing; hence, land use integrating contractual grazing is practised by only $10 \%$ enclosure owners in this location.

The grazing, cultivation and fodder production management regime integrates rearing of improved breeds, cultivation of maize and beans, and cultivation of high-yielding grass varieties. This regime has been necessitated by two factors: (1) reducing availability of natural pasture due to increasing uptake of crop-based regimes in the wetter regions of Chepareria and (2) intensification in livestock production (through improved breeds) and ready market for livestock marketable products, particularly milk. These factors necessitate households to practise fodder production in order to ensure sufficiency/stability in pasture availability and stability in milk production. The regime is therefore prevalent in Ywalateke location (13.3 \%) located in the wetter regions of Chepareria. Notably, it is less practised in the drier areas of Chepareria by only $3.3 \%$ and $0 \%$ in Chepkopegh and Morpus locations. Under proper management, it is possible to optimize Chepkopegh and Morpus locations in zone $\mathrm{V}$ to this regime. However, rainfall and inadequate finances to invest in capital 
intensive practices such as irrigation are key limiting factors hindering enclosure owners in the location. Our results are similar to findings in previous studies which indicated that fodder production in enclosures not only enables enclosure owners to stock fodder for use during the dry season (Gaani et al. 2002; WOCAT 2003) but also presents opportunities for enclosure owners to earn income from sale of hay or grass seeds from the enclosure (Napier and Desta 2011).

\section{Crop-based enclosure management regimes}

The cultivation and grazing enclosure regime integrates intensive production of market-oriented crops and rearing of improved livestock breeds. Commonly cultivated crops within this regime include maize and beans. Individuals practising this regime tend to keep improved breeds which have higher productivity, particularly for milk, and higher demand in the market due to their productivity (milk and meat). Pasture availability for those inhabiting the wetter regions of Chepareria (Ywalateke) supports livestock production in this regime. This coupled with supplemental livestock feeds from crop residues maintains the production of livestock even during the dry period. It is therefore common in Ywalateke location (43.4 \%), which is a mixed farming livelihood zone (Fig. 2) which can support rain-fed agriculture. The increasing practice of this regime in the wetter regions of Chepareria reaffirms the observation of others (BurnSilver 2007; Galvin 2009). They all reported increasing adoption of crop cultivation among pastoralists in East Africa who inhabit areas that can support rain-fed production.

Factors influencing the choice of enclosure management regimes in Chepareria

In Chepareria, enclosures were established to provide dryseason grazing reserves (Makokha et al. 1999; Kitalyi et al. 2002). Initially, enclosures were only used as dry-season fodder reserves while livestock were grazed in the open range during the rainy season. However, the continuous establishment of enclosures in Chepareria has reduced the available communal land, hence restricting livestock grazing within individual enclosures only. With reduced communal and individual land holdings, the need to diversify and complement sources of household livelihood, particularly from land use among enclosure owners, is gaining momentum. While the dominance of livestock-based management regimes in our study reaffirms previous studies which report that enclosures in African rangelands were mainly established for livestock grazing (Gaani et al. 2002; Nedessa et al. 2005; Napier and Desta 2011), we have also observed agricultural diversification of land use among enclosure owners to include crop cultivation, contractual grazing and fodder/grass seed production.

\section{Agroecological zonation}

The upper altitude areas with wetter climates support more of rain-fed dependent production practices, hence the higher proportion of crop-based agropastoralism management systems and cultivation and grazing in Ywalateke. On the other hand, livestock-based agropastoralism regimes dominate further down the rainfall gradient. Variable and unpredictable rainfall in arid and semi-arid lands (ASALs) of sub-Saharan Africa (SSA) continues to curtail reliable crop production through rain-fed agriculture. The dominance of crop-based enclosure management regimes in the wetter regions of Chepareria supports previous studies that reported increasing adoption of crop farming among East African pastoralists inhabiting areas that support rain-fed agriculture (BurnSilver 2007; Galvin 2009).

\section{Land tenure}

Land ownership or lack thereof influences how individuals use their land. In Ethiopia, enclosure establishment through rangeland privatization by the state has been found to foster proper management and use of rangelands (McCarthy et al. 2003; Keene 2008; Napier and Desta 2011). It also offers independence in land management and utilization of enclosures in Somaliland (Gaani et al. 2002) and allows enclosure owners to practise what they wish with their land (independence) and gain the accruing benefits as is the case in Chepareria, West Pokot (Saxer 2014). While most individuals in Ywalateke have title deeds, those on the lower altitude areas (Chepkopegh and Morpus) still operate under the group ranch system although land boundaries are delineated and they have allotment letters/numbers (Saxer 2014). Enclosure owners in Ywalateke are significantly practising crop-based management regimes compared to those in Chepkopegh and Morpus, although livestock-based management regimes tend to predominate.

\section{Livestock owned}

Households with large herd sizes are likely to adopt livestock-based management regimes in place of cropbased regimes. This can be explained by the underlying positive correlation between the number of livestock owned by a household and its income.

\section{Household income}

The observed positive correlation between enclosure management regimes and household income can be explained by the underlying correlation between household income and number of livestock owned. The rich households are more likely inclined than are the poor households to diversify land use options and by extension management regimes, since the former do not find sufficient feeds for their large herds during the dry season. Wealth stratification influences not only enclosure 
regimes but also the decision to enclose land (Beyene 2010).

\section{Conclusion}

Enclosures were mainly established to address land degradation in Chepareria. However, the continuous adoption and adaptation of enclosures has also enabled agricultural diversification among enclosure owners in Chepareria as evidenced by the four enclosure management regimes identified. The dominance of livestockbased enclosure management regimes in Chepareria indicates that livestock production is still the mainstay of agropastoralists in Chepareria. More so, enclosure owners are increasingly engaging in crop-based enclosure regimes where and when rain-fed agriculture is possible for subsistence or for sale to satisfy existing market needs. With increasing flexibility on land use, livestock management and the adoption of alternative income-generating activities in Chepareria, enclosure owners may continue to diversify or intensify enclosure management regimes. However, agroecological zonation, land tenure, livestock owned and household income are significant factors which will continue to influence the choice of management regimes among agropastoralists in Chepareria. To ensure that restored areas in enclosures do not revert to their previous state, there is a need for research to be conducted to identify the impacts of enclosure management regimes/systems on rangeland rehabilitation in Chepareria.

\section{Competing interests}

The authors declare that they have no competing interests.

\section{Authors' contributions}

WJN was responsible for the research study and took lead in describing the study area and writing the results, discussion and conclusion. SMM helped draft the manuscript and also contributed to the discussion section. VOW reviewed the enclosure management section and the correlation they exhibit with land use. GN reviewed enclosure management systems. Together with SMM, he was instrumental in shaping the management system framework. In addition, GN contributed to the discussion section. All the authors have read and approved the final manuscript.

\section{Author details}

'Department of Land Resource Management and Agricultural Technology (LARMAT), University of Nairobi, P.O. Box 29053-00625, Nairobi, Kenya. ${ }^{2}$ Department of Forest Ecology and Management, Swedish University of Agricultural Sciences (SLU) 901 83, Umea, Sweden. ${ }^{3}$ Triple L Research Initiative, Uppsala, Sweden.

Received: 22 January 2015 Accepted: 4 August 2015

Published online: 07 September 2015

\section{References}

AU-IBAR (African Union - Interafrican Bureau for Animal Resources). 2012. Rational Use of Rangelands and Fodder Crop Development in Africa. AUIBAR, Nairobi, Kenya. www.au-ibar.org/component/jdownloads/finish/46-mg/ 907-rational-use-of-rangelands-and-fodder-crop-development-in-africa rational use of rangelands and fodder. Accessed 15 August 2014.

Bai, ZG, and DL Dent. 2006. Global assessment of land degradation and improvement: Pilot study in Kenya. Report 2006/01, FAO/ISRIC - Rome/Wageningen.
http://.isric.org/isric/webdocs/Docs/ISRIC_Report_2006_01.pdf. Accessed 10 February 2014.

Behnke, RH. 1986. The implications of spontaneous range enclosures for African livestock development policy. International Livestock Center for Africa (ILCA). ILCA ALPAN Network Paper No. 12. http://hdl.handle.net/10568/4255. Accessed 27 August 2014

Beyene, F. 2006. Informal institutions and access to grazing resources: Practices and challenges among pastoralists of Eastern Ethiopia. In 11th Biennial Conference of International Association for the Study of Common Property Resources on Survival of the Commons: Mounting Challenges and New Realities, Bali.

Beyene, F. 2010. Driving forces in the expansion of enclosure among pastoral and agropastoral herders in Ethiopia. Quarterly Journal of International Agriculture 49(2): 127.

Beyene, F. 2011. Dismantling of common property, land use and pastoral livelihoods in eastern Ethiopia. Journal of Development and Agricultural Economics 3(10): 475-486.

BurnSilver, SB. 2007. Pathways of continuity and change: diversification, intensification and mobility in Maasai. PhD diss. Grad. Degree Program Ecol., Colo. State Univ., Fort Collins, CO.

County Government of West Pokot. 2013. First County Integrated Development Plan 2013-2017. http://www.westpokot.go.ke/images/downloads/ CIDPfinaldraft.pdf. Accessed 8 December 2014.

Ejigu, K, T Gebey, and T Preston. 2009. Constraints and prospects for apiculture research and development in Amhara region, Ethiopia. Livestock Research for Rural Development 21(10):172.

Fratkin, E. 2001. East African pastoralism in transition: Maasai, Boran, and Rendille cases. African Studies Review 44(3): 1-25.

Gaani, MX, CY Axmed, MC Kille, MJ Ibraahim, CM Axmed, and X Ibraahim. 2002. Regulating the livestock economy of Somaliland. Somaliland (Draft Only): Academy for Peace and Development Hargeysa.

Galvin, KA. 2009. Transitions: Pastoralists living with change. Annual Review of Anthropology 38:185-198.

Kandagor, DR. 2005. Rethinking pastoralism and African development: A case study of the Horn of Africa. Proceedings from lecture, Egerton University, Njoro. HYPERLINK http://www.codesria.org/IMG/pdf/kandagor.pdf"www.codesria.org/ IMG/pdf/kandagor.pdf. Accessed 25 August 2014.

Keene, FB. 2008. Incentives and outcomes of rangeland enclosures: A comparative institutional analysis among three (agro-) pastoral districts in eastern Ethiopia. Proceedings of the 12th Biennial Conference of the International Association for the Study of Commons (IASC), University of Gloucestershire, England.

Kigomo, JN, and GM Muturi. 2013. Impacts of enclosures in rehabilitation of degraded rangelands of Turkana County, Kenya. Journal of Ecology and the Natural Environment 5(7): 165-171.

Kirui, OK, and A Mirzabaev. 2014. Economics of land degradation in Eastern Africa No. 128. ZEF Working Paper Series 2014. Conference paper Tropentag 2014, Prague, Czeck Republic. doi:10.13140/2.1.1442.2400.

Kitalyi, A, A Musili, J Suazo, and F Ogutu. 2002. Enclosures to protect and conserve. For better livelihood of the West Pokot community. Regional Land Management Unit (RELMA). TECHNICAL PAMPHLET No. 2. HYPERLINK "http:// www.samsamwater.com/library/TP2_Enclosures.pdf"http:// www.samsamwater.com/library/TP2_Enclosures.pdf. Accessed 10 August 2014

KNBS (Kenya National Bureau of Statistics). 2009. The 2009 Kenya Population and Housing Census. HYPERLINK http://www.knbs.or.ke/index.php?...2009"http:// www.knbs.or.ke/index.php?...2009. Accessed 10 August 2014.

MA (Millennium Ecosystem Assessment). 2005. Ecosystems and human well-being: Desertification synthesis. Washington, DC: World Resources Institute.

Makokha, W, S Lonyakou, M Nyang, KK Kareko, C Holding, TJ Njoka, and A Kitalyi. 1999. We work together: Land rehabilitation and household dynamics in Chepareria Division, West Pokot District, Kenya. RELMA Technical Report No. 22. Nairobi Kenya: RELMA/SIDA. ISBN 9966-896-42-2. pp. 81.

McCarthy, N, A Kamara, and M Kirk. 2003. Cooperation in risky environments: Evidence from Southern Ethiopia. Journal of African Economy 12: 236-270.

Mekuria, W, E Veldkamp, H Mitiku, J Nyssen, B Muys, and K Gebrehiwot. 2007. Effectiveness of exclosures to restore degraded soils as a result of overgrazing in Tigray, Ethiopia. Journal of Arid Environments 69: 270-284.

Mureithi, SM, A Verdoodt, and E Van Ranst. 2010. Implications of enclosures for rehabilitating degraded semi-arid rangelands: A review of critical lessons from Lake Baringo Basin, Kenya. In Land degradation and desertification: Assessment, mitigation and remediation, ed. P Zdruli, 490. Dordrecht 
Heidelberg London New York: Springer. doi:10.1007/978-90-481-8657-0. $111-130$.

Mwilawa, AJ, DM Komwihangilo, and ML Kusekwa. 2008. Conservation of forage resources for increasing livestock in traditional forage reserves in Tanzania. African Journal of Ecology 46: 85-89.

Napier, A, and S Desta. 2011. Review of pastoral rangeland enclosures in Ethiopia.PLI Policy Project, USAID Ethiopia. http://fic.tufts.edu/assets/TuftsRange-Enclosure-Review-PLI.pdf. Accessed 24 August 2014.

NDMA (National Drought Management Authority). 2014. Drought Early Warning Bulletin - West Pokot County. National Drought Management Authority: Drought Monthly Bulletin for May 2014.

Nedessa, B, J Ali, and I Nyborg. 2005. Exploring ecological and socio-economic issues for the improvement of area enclosure management. A case study from Ethiopia. Drylands Coordination Group, Miljøhuset G9, Norway. http:// eldis.org/vfile/upload/1/document/0708/DOC18719.pdf. Accessed 23 August 2014.

Neely, C, S Bunning, and A Wilkes. 2009. Review of evidence on dryland pastoral systems and climate change: Implications and opportunities for mitigation and adaptation. Land and Water Discussion Paper: Food and Agriculture Organization of the United Nations.

Opiyo, FEO, WN Ekaya, DM Nyariki, and SM Mureithi. 2011. Seedbed preparation influence on morphometric characteristics of perennial grasses of a semi-arid rangeland in Kenya. African Journal of Plant Sciences 5(8): 460-468.

Reynolds, JF, FT Maestre, PR Kemp, DMS Stafford-Smith, and E Lambin. 2007. Natural and human dimensions of land degradation in drylands: Causes and consequences. In Terrestrial ecosystems in a changing world (pp. 247-257). Springer Berlin Heidelberg.

Saxer, Laura. 2014. A changing land tenure system and its social implications: The case of land enclosure processes in Chepareria, West Pokot, Kenya. MSc Thesis, University of Gothenburg.

Sposito, G. 2013. Soil. Encyclopædia Britannica Online Academic Edition. Web. Prod. Encyclopaedia Britannica Inc. 5 January 2015.

Svanlund, S. 2014. Carbon sequestration in the pastoral area of Chepareria, western Kenya - A comparison between open-grazing, fenced pasture and maize cultivations. MSc Thesis in Master of Science in Forestry: Swedish University of Agricultural Sciences (SLU).

UNEP. 2007. The Global Environment Outlook 4. Environment for development. Nairobi: UNEP.

Verdoodt, A, R Moussadek, S Mureithi, J Vermang, and L Ye. 2013. Opportunities and challenges in assessing and combating land degradation. In M. De Boever, M. Khlosi, N. Delbecque, J. De Pue, N. Ryken, A. Verdoodt, W. Cornelis, et al. (Eds.), Desertification and land degradation : processes and mitigation (pp. 35-42). Presented at the 4th Conference on Desertification and Land Degradation, Ghent, Belgium: Ghent University. UNESCO Chair of Eremology.

Verdoodt, A, SSM Mureithi, L Ye, and E Van Ranst. 2009. Chronosequence analysis of two enclosure management strategies in degraded rangeland of semi-arid Kenya. Agriculture, Ecosystems and Environment 129: 332-339.

Verdoodt, A, SM Mureithi, and E Van Ranst. 2010. Impacts of management and enclosure age on the recovery of herbaceous rangeland vegetation in semi-arid Kenya. Journal of Arid Environments 74: 1066-1073.

Wairore, JN. 2015. Influence of enclosure management systems on rangeland rehabilitation in Chepareria, West Pokot County, Kenya. MSc Thesis, University of Nairobi.

Wasonga, OV. 2009. Linkages between land-use, land degradation and poverty in semi-arid rangelands of Kenya: The case of Baringo District. PhD Thesis. University of Nairobi.

WOCAT. 2003. Area closure for rehabilitation. Ethiopia-Meret Mekelel. https:/ qt.wocat.net. Accessed 10 May 2015.

\section{Submit your manuscript to a SpringerOpen ${ }^{\circ}$ journal and benefit from:}

- Convenient online submission

- Rigorous peer review

- Immediate publication on acceptance

- Open access: articles freely available online

- High visibility within the field

- Retaining the copyright to your article

Submit your next manuscript at $\gg$ springeropen.com 